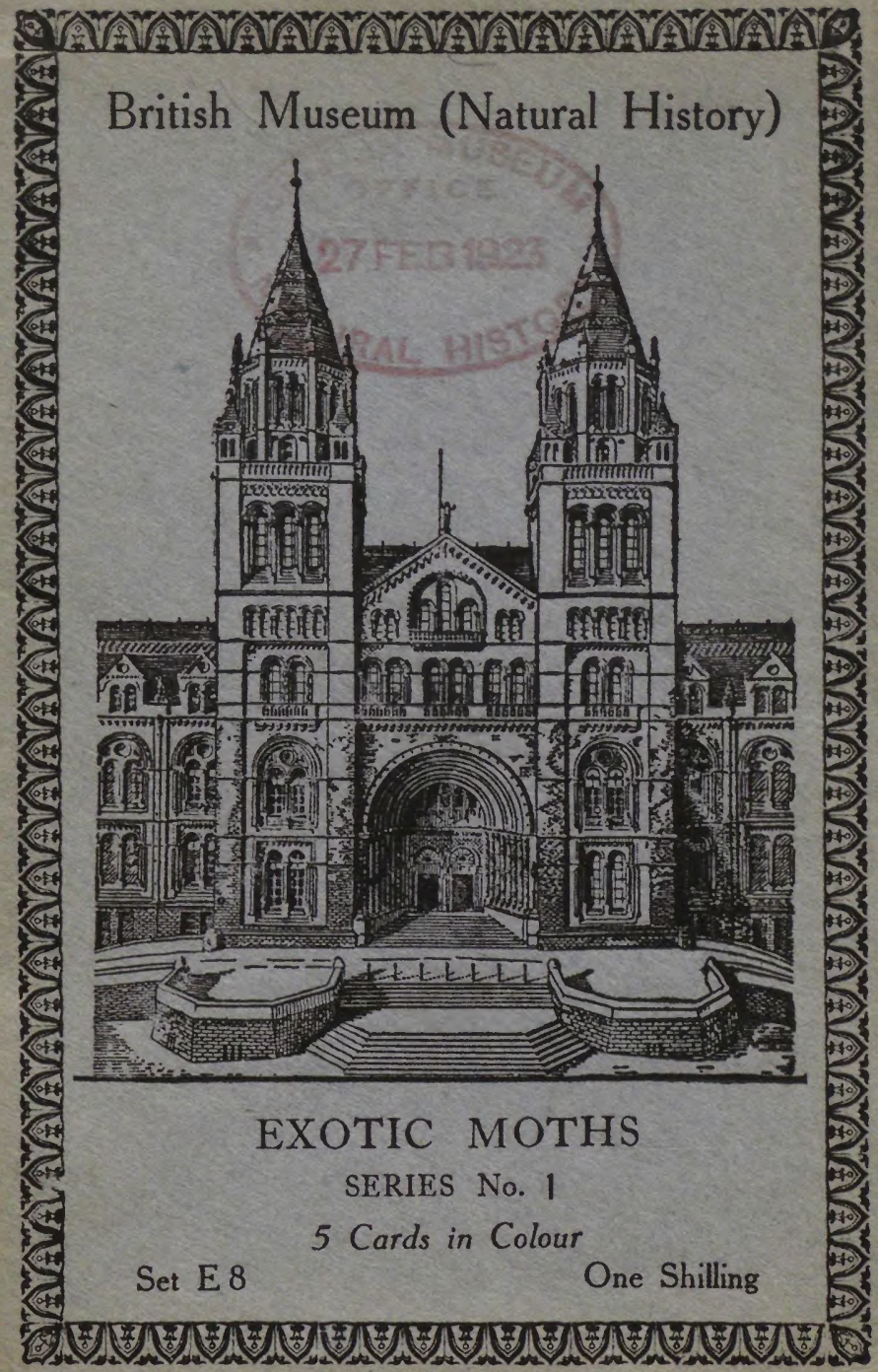




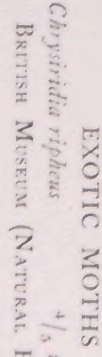

$$
\begin{aligned}
& \text { 플 } \\
& \pm \geq
\end{aligned}
$$$$
\text { ह }
$$

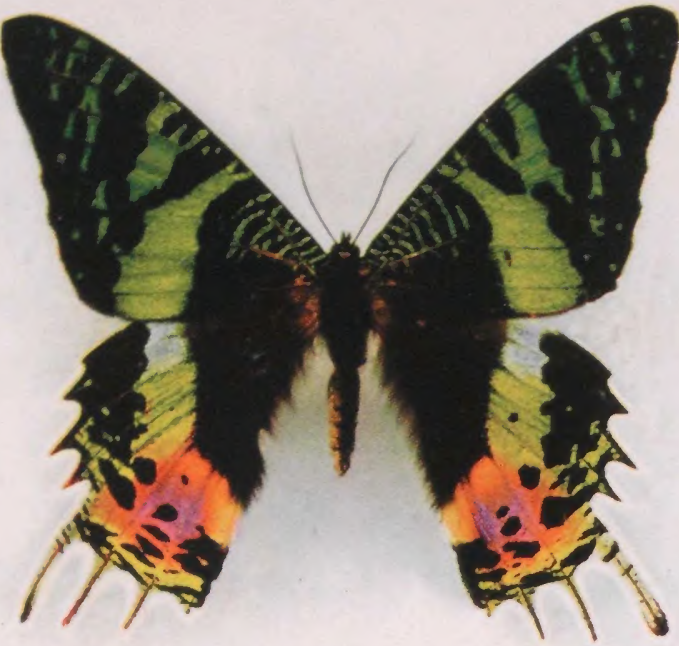




\section{POST CARD}

This Space may be, used for

(For ADDress ONLY)

CorRespondeNCE. 


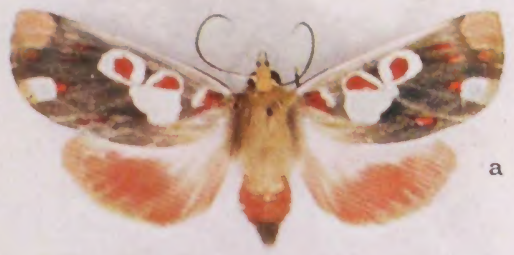

a

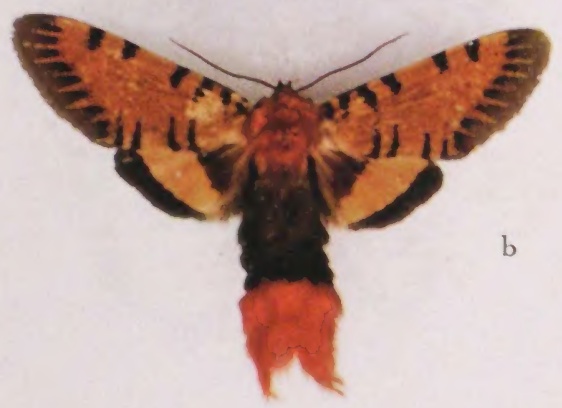

EXOTIC MOTHS
(a) Hypsidia erythropsalis
(b) Epicausis smithi Brttish Museum (Natural History)
$\%$ Is natural size

E 57 


\section{POST CARD}

ThIS Space May Be USED For Corresponinkser

(For ADDress ONLY) 

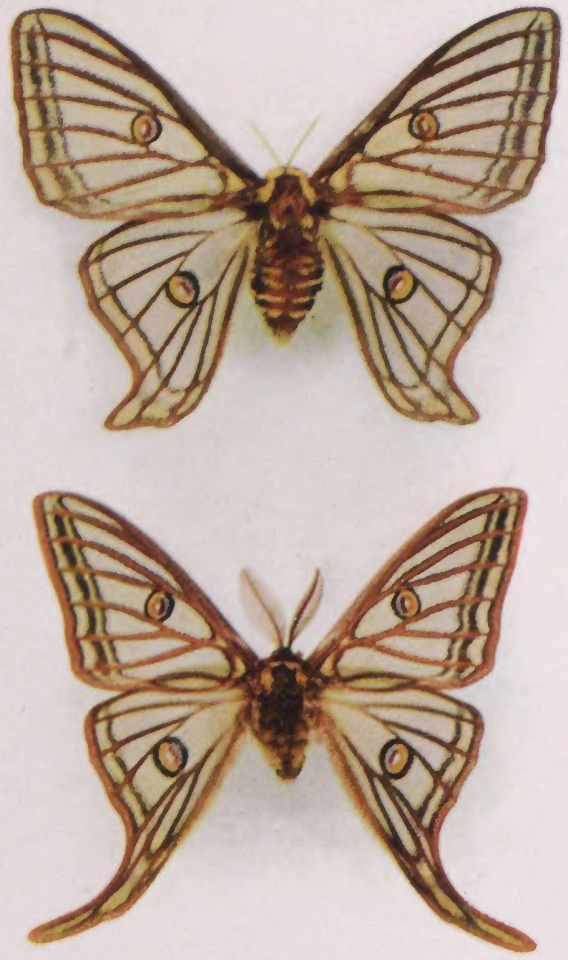

EXOTIC MOTHS

Graellsia isabellae $\quad$ /, natural size

British Musfum (Natural. History) 


\section{POST CARD}

This Srace may be USEd for CORRESPONDENCE

(FOR ADDREsS ONI.Y) 


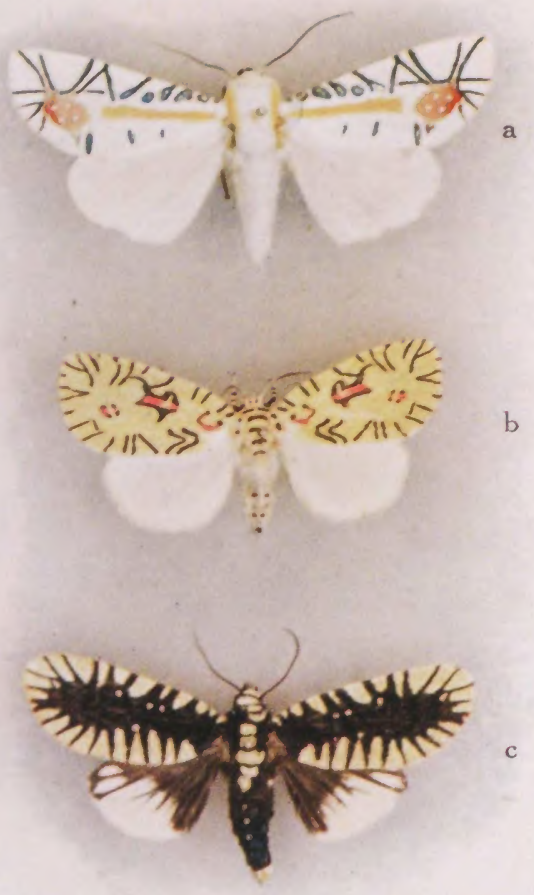

EXOTIC MOTHS
(a) Baorisa hieroglyphica
(b) Maæuca concinnula
(c) Apsarasa radians Natural size 


\section{POST CARD}

This Space may be used for Corraspondence

(For AdDREss ONLY) 


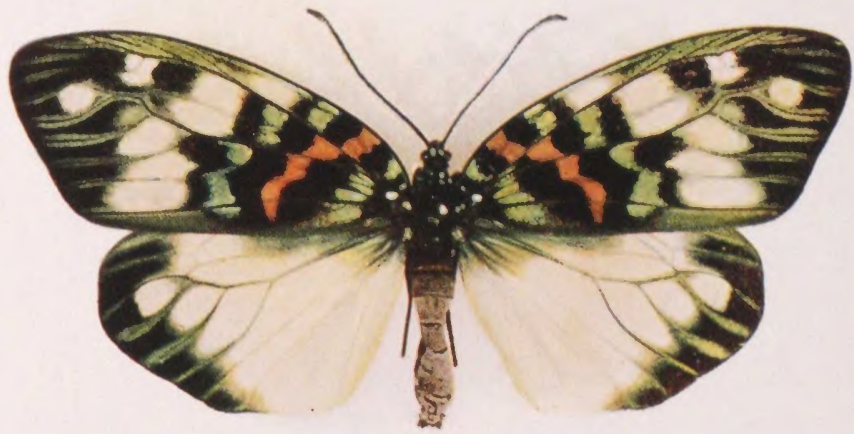




\section{POST CARD}

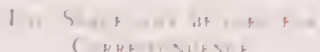

(1) A serpe ON 


\section{BRITISH MUSEUM (NATURAL History)}

\section{EXOTIC MOTHS.}

A few of the most beautiful and interesting moths found in various parts of the world are represented in this series. Two curious moths are shown from Madagascar, one resembling a butterfly. Various families are represented. The beautiful Graellsia isabellae, a relative of our Emperor Moth, is found only in Central Spain. One card shows three moths interesting for their extraordinary markings and contrasted colourings. These are but a small selection from the thousands of moths of striking coloration and remarkable structure to be found throughout the world, and particularly in the tropics.

\section{E $56 \quad$ Chrysiridia ripheus.}

This is a beautiful diurnal butterfly-like moth which is found in Madagascar. A closely related species occurs in Zanzibar and the adjacent region. Besides these two species, their only near relatives are found in tropical America and the West Indies. "Lolonandriana" or the King-butterfly is the native name of this insect, which in the adult state is well-known. The caterpillar is cylindrical, about $2 \frac{1}{2}$ inches long, yellowish in colour, spotted and stippled with black. It is covered with long, 
spatulate blackish hairs, and bears a thoracic shield coloured like the rest of the body. The underside is yellowish white, the legs dotted with black. It feeds on one of the Euphorbiaceae (Omphalea), called by the natives "Huzo-Malay," and when full-fed turns into a chrysalis in a fine-meshed net-like cocoon. The various stages from the egg to the moth are found from January to May in the temperate heights in the centre of the island, but in the warm and little elevated coastal regions are found nearly all the year round.

\section{E 57 (a) Hypsidia erythropsalis.}

This beautiful Australian moth belongs to a very large family, the Pyralidae, the members of which are mostly quite small moths, and usually not so strikingly coloured. The male of this moth has a remarkable window-like spot at the base of the fore wings, and beyond it, on the underside, a fold containing a tuft of long hairs. The pattern of the underside is very different from that of the upper side. The life-history of this species is unknown.

\section{E 57 (b) Epicausis smithi.}

Amongst the animals and plants of Madagascar are many remarkable species which are peculiar to that island. The moth illustrated is one of these indigenous insects, and belongs to a small subfamily of the Noctuidae, the Diphtherinae, which comprises less than 100 known species. The moths of this group possess hairy eyes. The life-history of this interesting insect is not known. 


\section{E 58 Graellsia isabellae.}

This beautiful moth is remarkable because it is the only European representative of the tailed green species of its family (Saturniidae), is not closely related to any other known species, and is restricted in distribution to Central Spain (Castile and Aragon). The caterpillar is green with a reddish-brown line bordered with white on its sides, which bear white tubercles studded with short hairs. It feeds on Pine in July, and the moth appears in the following May.

\section{E 59 (a) Baorisa hieroglyphica.}

This little-known moth is of singular beauty and striking pattern. It was first found at Darjeeling in Sikhim, and has since been taken in Assam and the Philippine Islands. Nothing is known of its life-history.

\section{E. 59 (b) Mazuca concinnula.}

This is a well-known African moth, very conspicuously coloured, and with a remarkable pattern. Its early stages are at present unknown.

\section{E 59 (c) Apsarasa radians.}

Four species of Apsarasa have so far been discovered. The one figured is perhaps the best known of these strangely marked moths, and is found in Sikhim and Assam. One species occurs in the Andaman Islands, one in Gilolo (between Celebes and New Guinea), and another in New Guinea. Their life-histories are not yet known. 
This moth, various races of which are found in India, China and Japan, is distantly related to the European Burnet Moths, though it belongs to a sub-family of the Zygaenidae not represented in Europe. The Burnets are able to exude from their bodies a yellow oily fluid when they are irritated. This fluid appears not only to render them distasteful to vertebrate animals, but also to protect them from predatory insects. This Oriental moth is apparently protected in a similar manner. It has the curious habit, when disturbed, of pumping out from just behind its head a mass of yellow foam as big as a gooseberry. The pumping action is accompanied by contractions of the abdomen, and by a slight hissing noise. The caterpillar is velvet-black, the warts pale red, and it has on its back a right-angled yellow spot spreading over two segments. It feeds on Wild Coffee, and spins its cocoon on a leaf.

Set E 8

Jamuary, 1923. 